\title{
A Case History Study of the Recycling Efforts from the United States Army Corps of Engineers Hurricane Katrina Debris Removal Mission in Mississippi
}

\author{
Dennis Leroy Brandon, Victor Frank Medina, and Agnes Belinda Morrow \\ Engineer Research and Development Center, US Army Corps of Engineers, 3909 Halls Ferry Road, Vicksburg, MS 39180, USA
}

Correspondence should be addressed to Dennis Leroy Brandon, dennis.l.brandon@usace.army.mil

Received 1 March 2011; Revised 9 June 2011; Accepted 15 June 2011

Academic Editor: Monica Prezzi

Copyright (C) 2011 Dennis Leroy Brandon et al. This is an open access article distributed under the Creative Commons Attribution License, which permits unrestricted use, distribution, and reproduction in any medium, provided the original work is properly cited.

In support of the Federal Emergency Management Agency (FEMA), the US Army Corps of Engineers (USACE) managed the removal of Hurricane Katrina storm debris in several states. This paper focuses on the debris removal practices in 16 southern Mississippi counties and the recycling efforts. Debris was removed from public and private property. The debris included vegetation, construction material, electronic waste, vehicles, and vessels. The scope of the USACE mission was expanded several times. The scope within the respective counties varied from vegetation only to the removal of every eligible form of debris. The recommendations proposed should enhance recycling efforts during future debris removal missions.

\section{Introduction}

Hurricane Katrina was the costliest natural disaster in American history, generating more than 90.2 million $\mathrm{m}^{3}$ of debris across Louisiana, and Mississippi. The Federal Emergency Management Agency (FEMA) assigned the US Army Corps of Engineers (USACE) responsibility for debris removal in localities where local governments were not capable of handling debris removal [1]. The USACE Vicksburg District managed the removal of more than 15.1 million $\mathrm{m}^{3}$ of debris from 16 southern MS counties (Figure 1): Clarke, Covington, Forrest, George, Greene, Hancock, Harrison, Jackson, Jones, Lamar, Leake, Lincoln, Newton, Perry, Pike, and Walthall [2]. The extent of the USACE mission in each county was determined by the county supervisors or the governing officials in each municipality. Debris removal was conducted between September 2005 and September 2006, and was essentially complete in the northern counties by April 2006. In Hancock, Harrison, and Jackson counties, debris removal continued until September 2006. In these counties, the USACE's expanded mission included debris removal from swimming pools, the removal of concrete foundations, and the removal of vehicles and vessels. This paper reviews the procedures utilized during Hurricane Katrina debris removal and the recycling practices during that mission. In addition, the paper recommends changes from the Katrina experience to enhance recycling.

\section{Description of the Corps of Engineers Debris Removal Mission}

2.1. Goals of the Federal Debris Removal Mission. The debris removal goal of USACE was to manage all storm debris in a timely, efficient, cost-effective manner that also achieves environmental compliance [3]. To be eligible for removal by the Federal response, the debris removal must be in the "public interest," which was defined as (1) eliminates immediate threats to life, public health and safety, (2) eliminates immediate threats of significant damage to improved property, and (3) ensures economic recovery of the affected community to benefit the community at large [3]. If debris did not meet this criteria, then its removal was the responsibility of the local land owner or the municipality.

2.2. Debris Categories. The debris was categorized as vegetative, household hazardous waste, construction and demolition, white goods, electronic, vehicular, or marine vessel. 


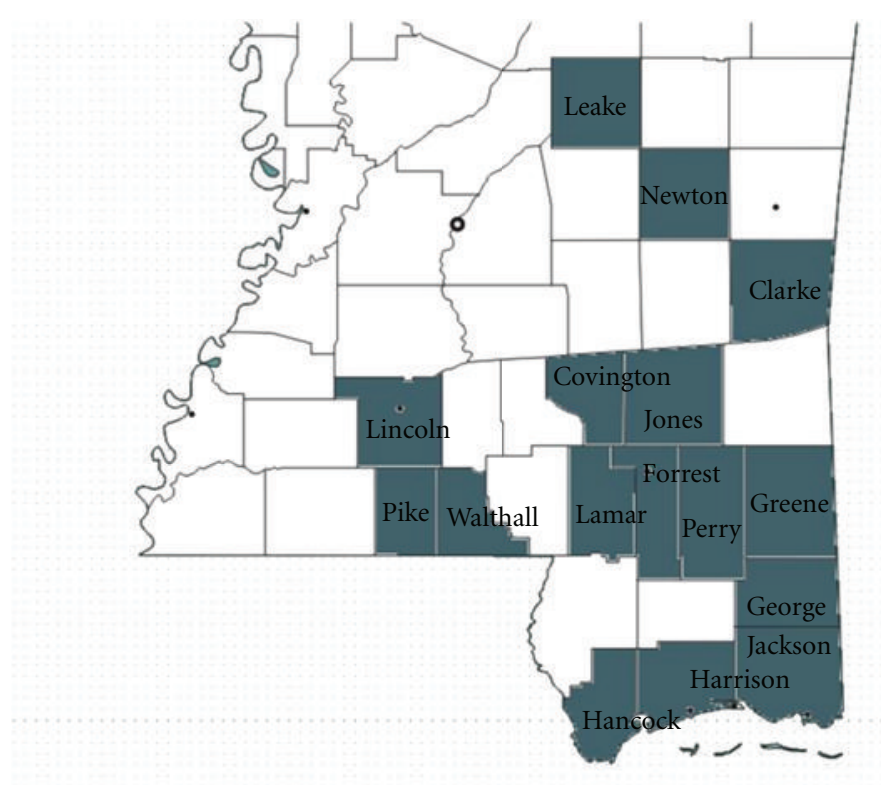

FIgure 1: Mississippi County map. Counties that had their debris removal missions managed by the USACE are shaded and have name labels.

Vegetative debris consists of whole trees, tree stumps, tree branches, tree trunks, and other leafy material. A tree is considered hazardous if it is an immediate threat to lives, public health, and safety, or improved property. Leaners are trees leaning at an angle greater than 30 degrees. Hangers are damaged limbs still hanging from tree branches [3]. Leaners and hangers are an immediate threat to life and safety. Leaners and hangers constitute a significant proportion of the vegetative debris removed. Household hazardous waste is used or leftover contents of consumer products that contain chemicals defined in regulatory terms under the Resource Conservation and Recovery Act. These wastes appear on one of the four hazardous waste lists or exhibit one of the following characteristics: ignitability, corrosivity, reactivity, or toxicity. Examples of household hazardous waste include small quantities of normal household cleaning and maintenance products, latex and oil based paint, cleaning solvents, gasoline, oils, swimming pool chemicals, pesticides, and propane gas cylinders. Construction and demolition debris can be defined as damaged components of buildings and structures such as lumber and wood, gypsum wallboard, glass, metal, roofing material, tile, carpeting and floor coverings, window coverings, pipe, concrete, fully cured asphalt, equipment, furnishings, and fixtures. White goods were defined as discarded household appliances such as refrigerators, freezers, air conditions, heat pumps, ovens, ranges, microwave ovens, space heaters, dishwashers, washing machines, clothes dryers and water heaters. Many white goods contain ozone-depleting refrigerants, mercury, or compressor oils that required removal and processing to protect the environment before the white goods could be recycled. Electronic waste (e-waste) refers to electronics that contain hazardous materials, such as cathode ray tubes, computer monitors and televisions. Typically, these products contain minerals and chemicals that require specific disposal methods [3]. Vehicular refer to automobiles, trucks, bases, campers, motorcycles, and golf carts. Marine vessels include boats, trailers, and jet skis.

2.3. Types of Removal. The debris removal efforts were classified as either right of entry (ROE) or right of way (ROW). ROE involves debris removal from private property that was conducted to meet the goals discussed above. Because it involved access to private property, ROE removals required documentation by which a property owner confers to the USACE the right to enter onto private property for debris removal without committing trespass. In instances where the property owner was not available, the USACE obtained documentation from the local government to conduct debris removal. The USACE created an ROE file for each parcel entered. The ROE file documented site hazard assessments, coordination with the owner and subcontractor(s), FEMA approval and any historical preservation society assessment. ROW refers to portions of land over which facilities such as highways, railroads, or power lines are built. These are generally public lands and included land on both sides of the facility up to a private property line [3]. The types of debris placed in the ROW or removed through ROE were determined by local governing officials.

2.4. Debris Management. Figure 2 outlines USACE debris management procedures used during the Hurricane Katrina response. Vegetative debris, construction and demolition 


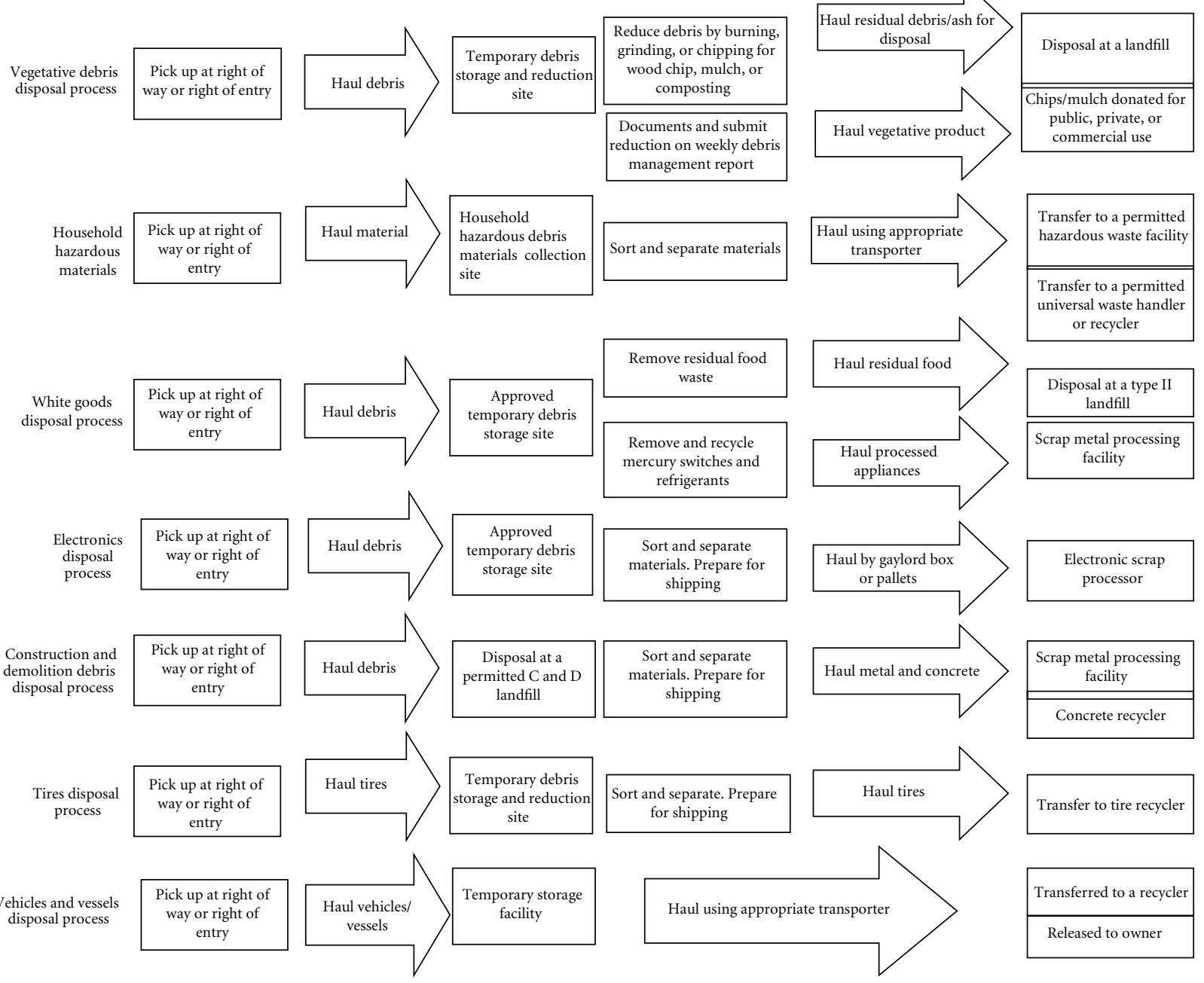

FIGURE 2

debris, household hazardous waste, white goods, and electronic wastes were segregated and placed in the ROW. Generally, homogenous loads of vegetative debris, white goods, and electronic wastes were transported to temporary debris storage and reduction sites (TDSRS), placed in separate storage locations, further processed, and then reduced or transferred to a recycling facility. Construction and demolition debris was transported to permitted landfills or TDSRS. Household hazardous waste was hauled to collection sites, sorted, and transported to permitted hazardous waste facilities or universal waste handlers. ROE debris removal also involved homogeneous loads of debris removed from private property and debris placed in the ROW. The vegetative debris included downed trees and leaners and hangers removed from ROW or ROE. These were transported to TDSRS sites. The construction and demolition debris was derived from demolition, structural collapse, or offsite sources.

TDSRS were established to facilitate waste reduction and reuse. The USACE established 44 TDSRS in 16 southern
Mississippi counties, which were used exclusively for the USACE removal mission (Table 1). TDSRS were established on private property, public property, and permitted landfills [4-6]. Table 2 provides basic debris management costs from the USACE contract with AshBritt Environmental, who served as the primary contractor [2]. Additionally, the USACE performed the removal of storm-damaged vehicles, vessels and removed debris from swimming pools in selected jurisdictions [7]. The USACE base plan was to achieve all debris removal using cost elements of the AshBritt contract. The cost savings discussed in this paper are reductions from the base plan. These costs do not include USACE administrative costs.

2.5. Recycling in the Debris Removal Mission. Recycling disaster-related debris has financial and environmental advantages. These operations can decrease the overall cost of a debris removal operation by reducing the amount of debris that is taken to a landfill. This diminishes the cost of final disposition in the form of tipping fees, which are 
TABle 1: Debris $\left(\mathrm{m}^{3}\right)$ removed from ROE and/or ROW in 16 Mississippi counties.

\begin{tabular}{|c|c|c|c|c|c|c|}
\hline County & Debris type ${ }^{@}$ & Total debris & ROE & ROW & No. TDSRS & Vegetation reduction \\
\hline Clarke & $\mathrm{V} ; \mathrm{CD}$ & 72,509 & 0 & 72,509 & 2 & $\mathrm{I}(2)^{*}$ \\
\hline Covington & V; CD; HH; WG; EW & 346,223 & 56,497 & 289,726 & 3 & I (3) \\
\hline Forrest & V; CD; HH; WG; EW & $1,876,870$ & 255,422 & $1,621,448$ & 5 & I (1); G (5) \\
\hline George & V; CD; HH; WG; EW & 480,970 & 165,658 & 315,312 & 2 & G (1) \\
\hline Greene & $\mathrm{V}$ & 3,782 & 0 & 3,782 & 1 & $\mathrm{I}(1)$ \\
\hline Hancock & V; CD; HH; WG; EW;VV & $4,137,377$ & $1,617,215$ & $2,520,162$ & 6 & $\mathrm{I}(1)$ \\
\hline Harrison & V; CD; HH; WG; EW;VV & $1,046,314$ & 548,391 & 497,923 & 1 & $\mathrm{G}(1)$ \\
\hline Jackson & V; CD; HH; WG; EW;VV & $3,324,483$ & 609,073 & $2,715,410$ & 6 & $\mathrm{G}(1)$ \\
\hline Jones & $\mathrm{V} ; \mathrm{CD} ; \mathrm{WG}$ & $1,474,217$ & 0 & $1,474,217$ & 4 & I (2); G (2) \\
\hline Lamar & V; CD; HH; WG; EW & $1,122,628$ & 212,905 & 909,723 & 4 & I (1); G (3) \\
\hline Leake & $\mathrm{V} ; \mathrm{CD}$ & 28,602 & 0 & 28,602 & 1 & I (1) \\
\hline Lincoln & $\mathrm{V}$ & 82,301 & 0 & 82,301 & 2 & $\mathrm{G}(2)$ \\
\hline Newton & $\mathrm{V} ; \mathrm{CD}$ & 79,820 & 0 & 79,820 & 1 & $\mathrm{I}(1)$ \\
\hline Perry & V; CD; HH; WG; EW & 417,439 & 70,006 & 347,433 & 2 & I (1); G (1) \\
\hline Pike & $\mathrm{V}$ & 252,811 & 0 & 252,811 & 2 & G (2) \\
\hline Walthall & $\mathrm{V}$ & 395,686 & 0 & 395,686 & 2 & $\mathrm{G}(2)$ \\
\hline Grand Total & & $15,142,032$ & $3,535,167$ & $11,606,865$ & 44 & $\mathrm{I}(14) ; \mathrm{G}(20)$ \\
\hline
\end{tabular}

${ }^{\circledR}$ V: vegetative; CD: construction and demolition; HH: household hazardous waste; WG: white goods; EW: electronic wastes; VV: vehicles and vessels. * I (\#): incineration reduction method (no. TDSRS where incineration was used).

$\mathrm{G}(\#)$ : grinding reduction method (no. TDSRS where grinding was used).

TABLE 2: Basic debris management costs from the AshBritt environmental contract [2].

\begin{tabular}{lc}
\hline Task & Debris Management Costs \\
\hline Debris hauling & $\$ 20.93$ to $\$ 27.47$ per $\mathrm{m}^{3}$ \\
Tipping fee & $\$ 3.27$ to $\$ 4.58 \mathrm{per} \mathrm{m}^{3}$ \\
Reduction & $\$ 5.89$ per m $^{3}$ \\
Haul reduced debris & $\$ 6.54$ per m \\
ROE debris removal & $\$ 280.00$ per crew hour \\
Extracted stumps & $\$ 250.00$ to $\$ 700.00$ each \\
Leaners and hangers & $\$ 50.00$ to $\$ 400.00$ each \\
Decommissioning structures & $\$ 2,500.00$ each \\
Demolition & $\$ 45.00$ per $\mathrm{m}^{3}$ \\
Segregation & $\$ 230.00$ per crew hour \\
QA/S\&A/site management & $\$ 6.54$ per $\mathrm{m}^{3}$ \\
White goods with putrefied food & $\$ 45.00$ each \\
removal &
\end{tabular}

costs charged by landfills to dispose of solid waste in their facilities. In the case of recycling, potential end-use products for specific markets may offset the cost of operations [3].

Conversely, recycling efforts may conflict with the goals of the debris removal. Often, removal had to be done quickly-particularly when rapid removal was needed to create right of ways or to deal with an immediate safety hazard. Debris hauling vehicles usually did not contain separate compartments. Building demolitions many times could not, and even when they could were not, conducted in a step by step manner allowing for separation of recyclable components. However, recycling efforts were implemented in several areas and these are discussed in the next section.
2.6. Implementation of Recycling. The actions of the resident engineer, equipment selected by the subcontractors, and decisions by county and municipal officials were important in recycling performed during the Hurricane Katrina Response. The USACE established one regional office and several local offices that directed removal in one or more counties. Each office was managed by a resident engineer. Some of the recycling efforts discussed in this paper resulted from the personal initiatives of the resident engineer. Interestingly, resident engineers frequently changed positions during the cleanup, which sometimes resulted in changes in recycling efforts. Recycling efforts were also impacted by debris removal and reduction options utilized by contractors. Actual debris removal was conducted by contractors. The AshBritt contract did not specify which debris removal methods and reduction options would be utilized in any locality. In many cases, the contractors made decisions that affected recycling efforts. Finally, county and municipal officials affected recycling. These officials determined the types of debris removed. Because the debris removal requirements and vegetative debris reduction methods varied, county-tocounty comparisons are difficult. Further, recycling and reuse efforts varied substantially from location to location and even over time.

\section{Description of Recycling Efforts Undertaken as Part of the Corps of Engineers Debris Removal Mission}

3.1. Recycling Vegetative Debris. Vegetative debris is generally not hazardous, but can be challenging because it is bulky and consumes a substantial volume of landfill space. During the USACE Katrina response, more than $85 \%$ of the vegetative 


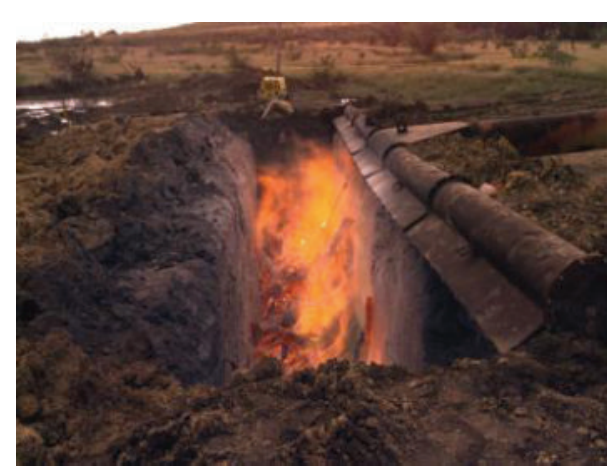

(a)

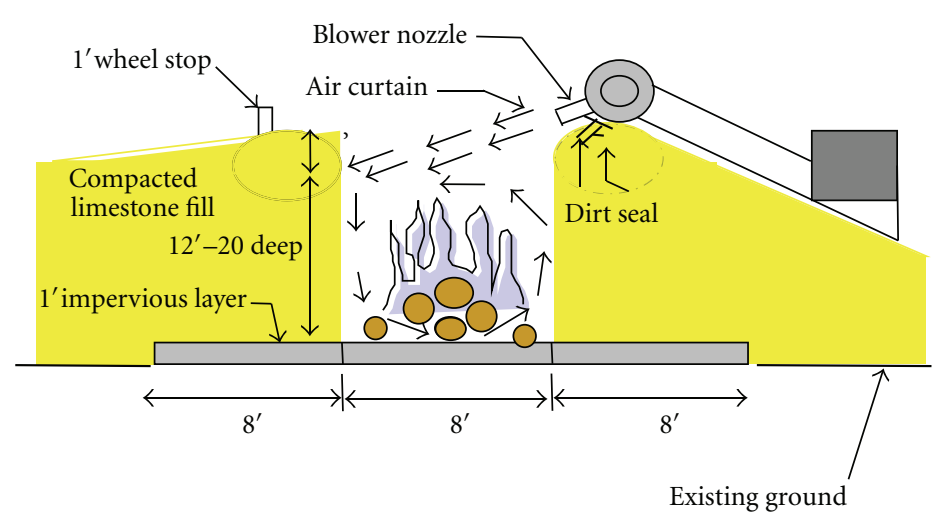

(b)

FIgURE 3: Below-grade air curtain incineration.

debris was hauled to TDSRS. Two methods of vegetative waste reduction were used: incineration and grinding. Air curtain pit (Figure 3) incineration was used at 14 TDSRS (Table 1). Incineration was a very effective means of volume reduction, reportedly achieving 95\% volume reduction [3]. Although ash could have some recycling possibilities, such as filler material for bricks or for filler material in road construction, ash was not recycled as part of the USACE Katrina response.

Chipping/grinding operations were used at 20 TDSRS (Table 1), and reportedly achieved a volumetric reduction of up to $75 \%$ [3]. Chips ground from vegetative debris were used beneficially as landscaping mulch, and as a boiler fuel source. In several counties, all of the debris hauled to TDSRS was vegetative (Lincoln, Pike, Walthall). For example, in Pike County, 252,811 $\mathrm{m}^{3}$ (Table 1) of vegetative debris resulted in approximately $63,203 \mathrm{~m}^{3}$ of mulch. All of the mulch from these three counties was used beneficially. This accomplishment was aided by the local distribution of hand bills, publishing the availability of mulch in local newspapers and an agreement with a chip mill. The Walthall County agreement stated that [8] “... Jones Chip Mill will have the responsibility and obligation of removing and hauling all of the chipped/ground vegetative debris from each of the designated sites above at no cost to the Government ..." This allowed the USACE to save the typical reduced debris hauling and tipping fees (i.e., \$9.81-\$11.12 per $\mathrm{m}^{3}$; Table 2). Assuming a $\$ 10$ hauling and tipping fee, the Pike County costs saved on mulch were over $\$ 600,000$. In some cases, large woody debris, such as logs, proved to be valuable resources without any reduction. For example, at one TDSRS in Walthall County, more than 900 logs were separated and donated to the property owner as part of the TDSRS agreement [6]. This resulted in a savings of \$15.70-\$17.01 per $\mathrm{m}^{3}$ (Table 2). Assuming an average log diameter of $0.38 \mathrm{~m}$ and length of $3.05 \mathrm{~m}$ and a reduction, hauling, and tipping cost of $\$ 16$ per $\mathrm{m}^{3}$, this resulted in a savings of just over $\$ 5000$.

Recycling of the vegetative material had several advantages. Valuable landfill space was conserved for other debris. The chipped vegetative material aided local residents in their recovery efforts and the industrial uses helped local

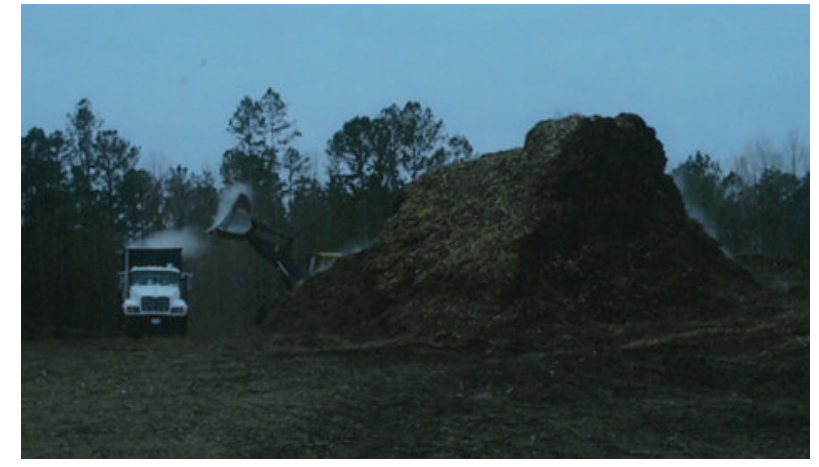

FIGURE 4: Smoldering chips in Lincoln County TDSRS in January 2006.

industries, which aided the local economy in its recovery effort. For USACE, the costs savings resulting from landfill disposal costs more than offset any costs of the chipping/grinding operation. Overall, chipping and grinding the vegetative material created the greatest opportunity for recvcling. However, this activity did create the potential for an undesirable outcome: fire. Smoldering occurred in several stockpiles of reduced vegetative debris in Lincoln and Pike counties (Figure 4). Mulch piles should be no higher than $4.57 \mathrm{~m}[3]$.

3.2. Building Materials. Prior to the demolition of any structures, site inspections were performed. These inspections assessed site utilities and identified site hazards (i.e., private wells, septic tanks, field lines, asbestos, flammable products, etc.). The demolition usually involved a trackhoe ripping the structure apart and loading fragments unto trucks. The construction debris was transported to landfills. Asphalt shingles, metal roofing and siding, bricks, CCA treated wood, untreated wood, and flooring materials were not segregated at the ROE (see Section 2.4).

Other household metal components were segregated on TDSRS (Figure 5), baled, and transported to scrap metal processing facilities. Home owners were permitted to move concrete foundations to the ROW for removal. Concrete was hauled to TDSRS (Figure 6) and placed in segregated 


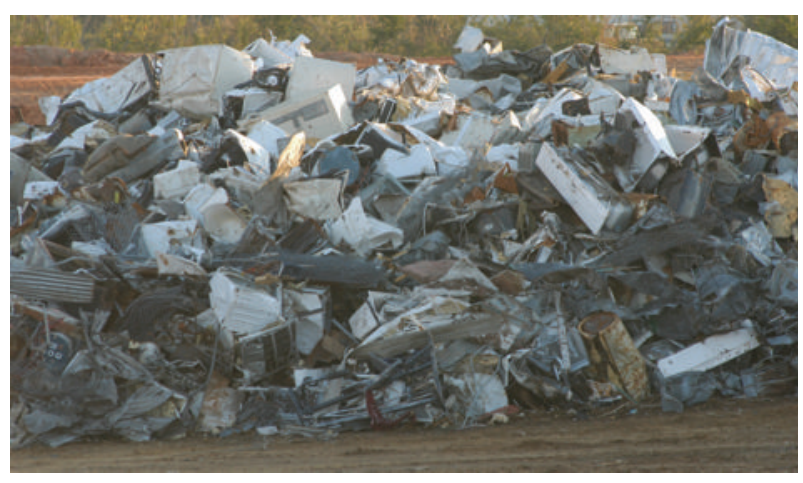

FIgURE 5: Metal segregated at the Firetower TDSRS in Harrison County, MS.

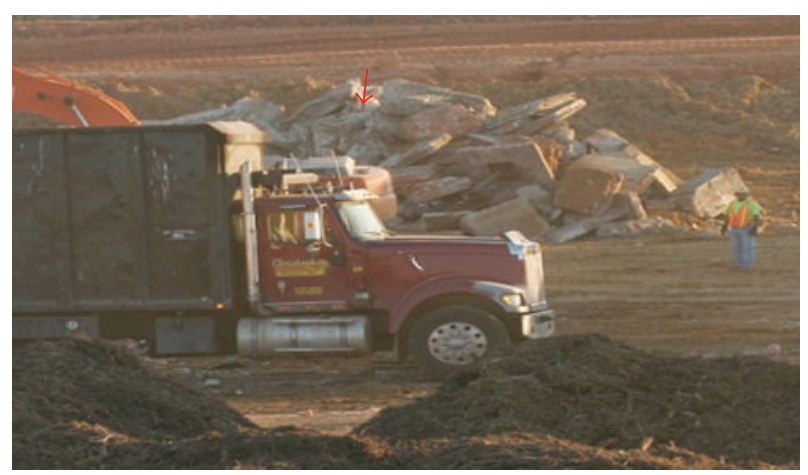

FIGURE 6: Concrete segregated at the Firetower TDSRS in Harrison County, MS.

locations. USACE personnel estimated there were $715 \mathrm{~m}^{3}$ of concrete in Pass Christian, MS, ROW on July 4, 2006 [9]. Concrete from Pass Christian, MS, was used to create aquatic habitat.

3.3. White Goods. Figure 2 summarizes the management of white goods. White goods were placed in the ROW (Figure 7), and subsequently transported to TDSRS (Figure 8) where refrigerants were removed and reclaimed from refrigerators, freezers, and air conditioners by certified technicians [1]. White goods were subsequently compressed, baled, and transported to scrap metal recyclers (Figure 9). This process not only recycled these chemicals, but kept them out of the environment where they can cause environmental damage, particularly ozone depletion [10]. The USACE processed 45,648 white goods in Hancock County and 4,386 white goods in Pass Christian, MS [11].

3.4. Electronic Wastes. Figure 2 summarizes the management of electronic wastes. Electronic wastes were collected from the ROW and transferred to TDSRS. Figure 10 shows a typical collection of electronic components being prepared for transport. E-waste was wrapped on pallets prior to shipping to the recycler (Figure 11).

3.5. Vehicles and Marine Vessels. Vehicles (automobiles, trucks, bases, campers, motorcycles, and golf carts) and

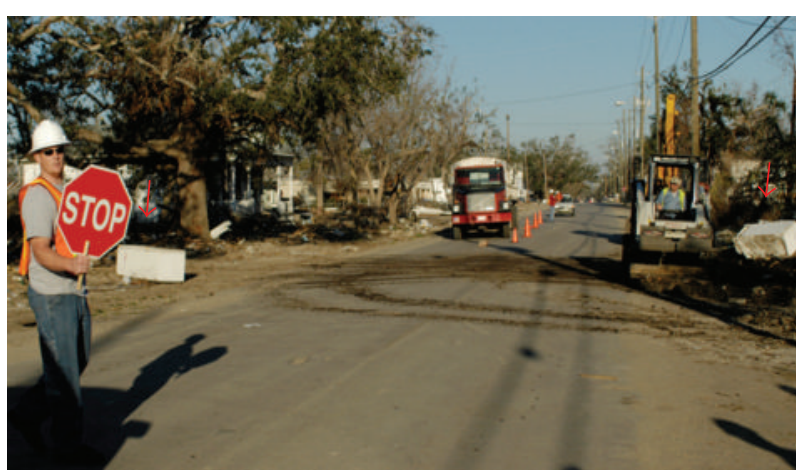

FIgURE 7: White goods placed in ROW to facilitate easy pick up in Pass Christian, MS.

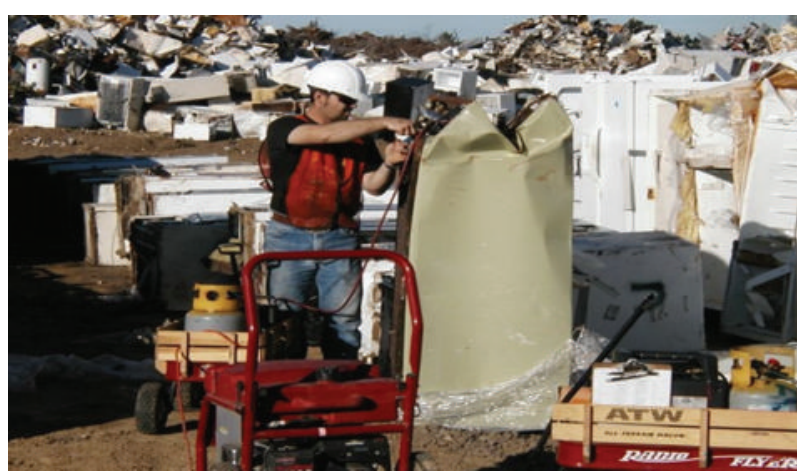

FIGURE 8: Refrigerant being reclaimed from white goods in Hancock County, MS.

marine vessels (boats, trailers, and jet skis) were moved great distances by tidal surge water, flooding, and wind during Hurricane Katrina (Figures 12 and 13). These bulky items frequently blocked roads and access points needed by recovery teams. In addition, they leaked gasoline, diesel fuel, and other hazardous chemicals. Vehicles and vessels were removed from ROW and ROE. For example, in the Pass Christian area, 350 vehicles and 358 marine vessels were removed as part of the debris removal mission [12]. All vehicles and vessels were towed by commercial towing contractors to designated staging locations. Scrap metal from reduced vehicles and vessels was also recycled.

3.6. Tires. As part of the debris management process, tires were segregate at the TDSRS (Figure 14). Tires were subsequently transported to recycling facilities. At least 42.53 metric tons of tires were recycled from Harrison County. Tires from Hancock County were transported to Gulfport Tire Recycling. Documentation shows that 162.61 metric tons of tires were recycled [13].

3.7. Recovery of TDSRS Sites. Following the removal of all storm debris, TDSRS were restored to as near preworking conditions as possible. They were reseeded with either local grasses or tree seedlings as requested by the landowners. The US Fish and Wildlife Service evaluated the design and closure plans for all TDSRS $[4,14,15]$. 


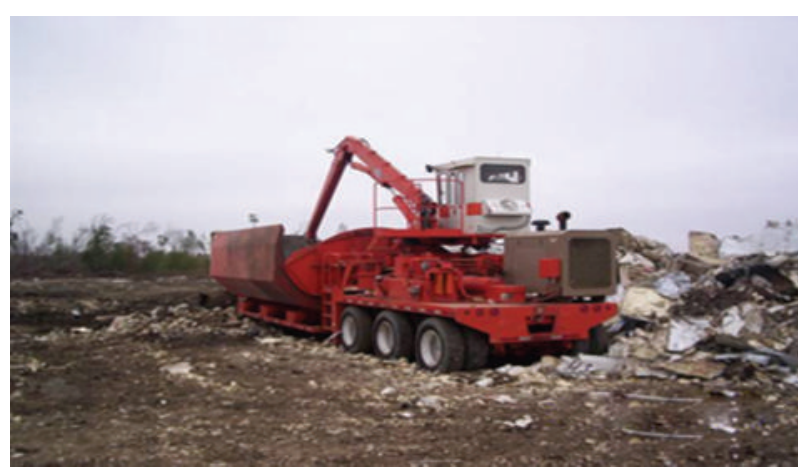

FIGURE 9: White goods were compressed, baled, and shipped to recycling facilities. Picture provided courtesy of USACE.

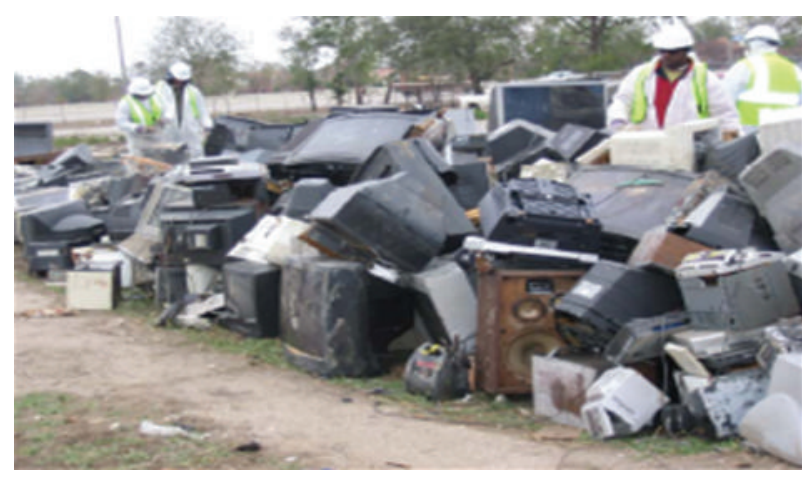

FIGURE 10: Collection of electronic waste. Picture provided courtesy of USACE.

\section{Discussion}

4.1. Recycling Vegetative Material Provides the Most Beneficial Effect. In review of the recycling efforts from Katrina, it is clear that recycling of plant material was the greatest success. Grinding and reuse of plant material created a valuable resource that was used in its entirety for those facilities that used this approach. In some cases, plant material was reused as whole logs. Focusing on vegetative material is critical, since this typically makes up a substantial portion of the debris generated during a large storm. All storm-related debris recovery plans should include plans for vegetative recycling.

Another opportunity could involve recycling of ash from burning of plant material. It is not clear if the volume of this material was large enough to justify a recycling effort, but uses for ash exist. Clean ash could be used as a material to make bricks and could also be used as a roadbase material [16].

4.2. Recycling Saves Valuable Landfill Space. The Hurricane Katrina generated more debris than any other natural disaster in US history, over $90 \times 10^{6} \mathrm{~m}^{3}$ [15]. For comparison, Hurricane Andrew (1992), for example, generated $33 \times$ $10^{6} \mathrm{~m}^{3}$ of debris in Metro Dade County, FL [17]. Hurricane Inike in Hawaii generated $3.8 \times 10^{6} \mathrm{~m}^{3}$, and Hurricane Hugo generated $1.5 \times 10^{6} \mathrm{~m}^{3}$ of plant waste. However, in all these cases, the solid waste generated by a disaster can

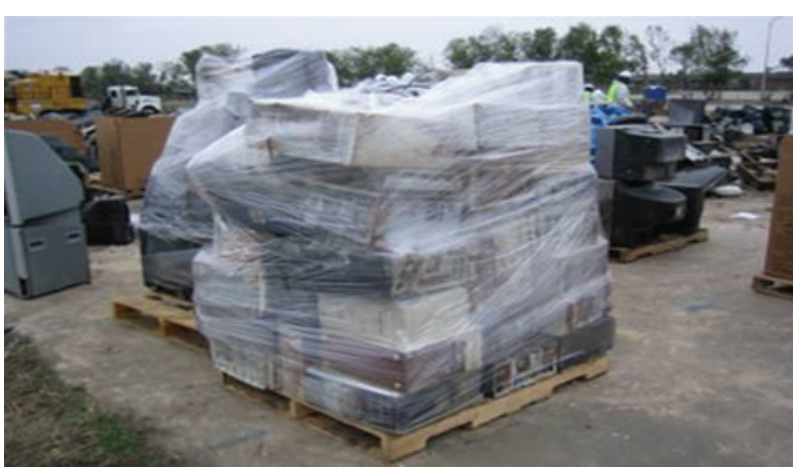

FIGURE 11: Electronic waste wrapped for shipping to electronic scrap processors. Picture provided courtesy of USACE.

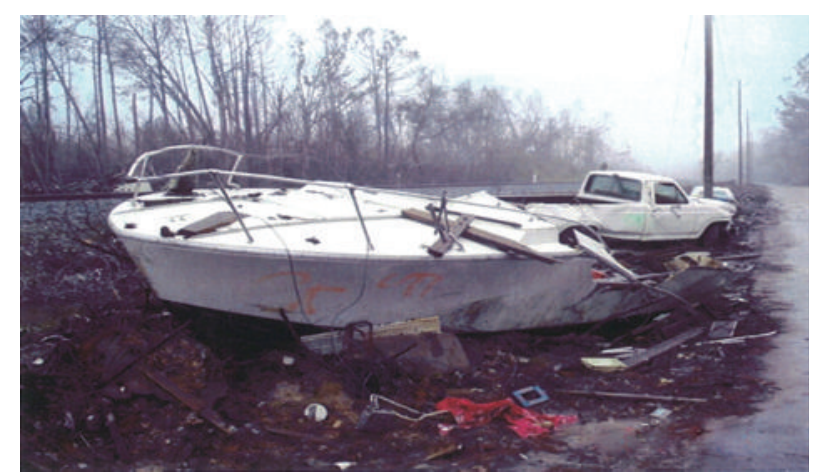

FIGURE 12: Vehicles and Vessel removed from Pass Christian, MS.

overwhelm existing solid waste disposal systems. Hurricane Hugo's volume of plant debris was on the order of 5- to 15times the annual solid waste produced in both North and South Carolina [17].

As shown in Table 1, the USACE debris mission in Mississippi totaled over 15 million $\mathrm{m}^{3}$. If only $10 \%$ of this material could be recycled, that would result in a savings of 1.5 million $\mathrm{m}^{3}$ of landfill space. Jackson is the largest city in the State of Mississippi with a Metro area population of over 500,000 . According to a report in $2004,2.72 \times 10^{6}$ metric tons of solid waste were disposed of in municipal landfills, which corresponds to about $5 \times 10^{6} \mathrm{~m}^{3}$ [18]. Therefore, even a $10 \%$ recycling rate would result in a substantial reduction in landfill use compared to normal solid waste operations. However, $10 \%$ recycling could be a very modest estimate of the potential.

4.3. Recycling Can Be an Effective Means of Dealing with Problematic Materials. Maximizing recovery and recycling could reduce landfilled wastes. Furthermore, recycling could be valuable for keeping problematic materials out of landfills. During Katrina, the recovery of refrigerants reduced the emission of these compounds into the atmosphere, where they could cause destruction of the ozone layer. Gypsum, which is frequently found in sheetrock, is a material that, if landfilled, can cause problem, as it can undergo anaerobic reaction to form foul smelling and potentially toxic hydrogen sulfide gas. However, it is possible to separate and recover 


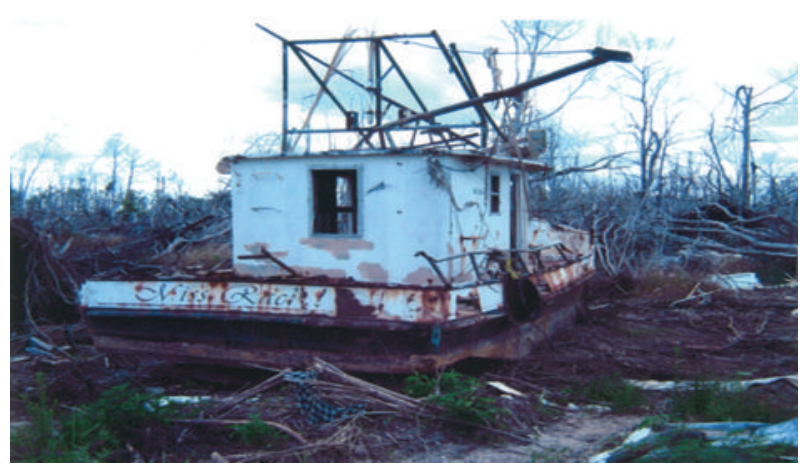

FIgURe 13: Vessel removed from Pass Christian, MS.

gypsum-containing sheetrock. The recovered gypsum can be utilized for stabilizing soil $\mathrm{pH}$ and can be used as a soil fertilizer [19-21].

4.4. Recycling of Debris Can Aid in Recovery. The debris itself, following separation/removal of any hazardous components, can also be a resource for the area to rebuild roads, buildings, and landfills. Inert soils and sediments, ground concrete, and mulched vegetative materials can be used for landfill covers, which are generally needed in large quantities. Concrete, asphalt road base, inert rocks, petroleum-contaminated soils, and ground asphalt shingles can be used by asphalt plants to repair or replace damaged roads [22]. Similarly, ground concrete, rocks, sand, and other materials can be used as aggregate for the new concrete needed for construction. Plant material can be composted and reused as fertilizer to promote new growth at damaged parks. Logs can be used to stabilize slopes and waterways [23]. For example, whole trees or large debris can be placed perpendicular to eroding banks to deflect the current and help to "train" the channel to a desired position. Studies on a Vermont river showed that adequate erosion protection was obtained for 4-5 years by using whole trees that were 0.6 to $0.9 \mathrm{~m}$ in diameter [24].

4.5. Building Demolition Is an Area of Potential Improvement. Building demolition can be a challenging issue; complicating building waste issues are home and office furniture, appliances, and computer equipment that is typically mixed with these wastes [25]. Furthermore, hazardous components can also be mixed in with the building material wastes, including asbestos (insulation in older homes, shingles, and flooring), lead (in lead-based paints and old plumbing systems), polychlorinated biphenyls (electrical transformers), chemicals and petroleum products, and mercury from electrical switching equipment $[17,23,26]$. However, the resulting building debris offers a tremendous opportunity for recycling. By assessing a building, before dismantling it, better results can be obtained regarding separation of hazardous and problem wastes and materials can be better recycled [25]. A program to develop guidance to rapidly assess buildings would be useful. Training programs could be developed to quickly train personnel in these techniques [23]. Phased demolition can maximize the recovery or reusable materials.

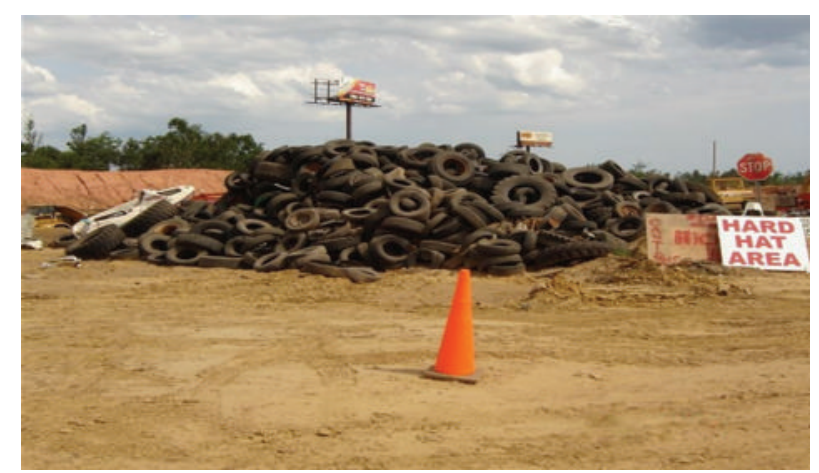

FIGURE 14: Tires segregated at Firestone TDSRS slated for recycling.

4.6. Staging Areas Are Critical for Reuse of Debris. Reuse and recycling requires staging areas where materials can be sorted and stockpiled. During Katrina, this was accomplished by establishing TDSRS sites. These areas proved to be very successful. Plans need to incorporate these areas for future disasters. In addition, plans need to include the restoration of these sites by regrading, planting, and so forth.

\section{Conclusion and Recommendations}

In conclusion, in spite of challenges due to the massive amount of debris generation, the USACE developed an effective approach for recycling debris. Development of TDSRS sites and policies on waste handling contributed to this success. Recycling saved valuable landfill space and provided useful products for recovery. The costs of recycling were partially offset by savings of landfill disposal costs. Strong planning is required for effective recycling to occur.

The USACE should modify the administrative staff to enhance the marketing and beneficial use of storm debris. This includes commercial and private use of reduced vegetative debris (i.e., chips, mulch, fertilizer, ash, etc.) and the use of logs for stream stabilization. This may involve modifying the contract to allow the USACE to determine the vegetative debris reduction method utilized in specific areas. Increased recycling of construction and demolition debris would require an enhanced assessment of structures and a better system of segregating components. The USACE should solicit proposals from recyclers willing to process segregated debris on TDSRS. Implementing these measures would increase USACE TDSRS costs but reduce the total USACE debris management costs (i.e., reduction, hauling, and/or tipping fees).

\section{References}

[1] Federal Emergency Management Agency, "Review of FEMA Guidance for Monitoring Debris Removal Operations for Hurricane Katrina," OIG-07-63 August 2007, http://www.dhs .gov/xoig/assets/mgmtrpts/OIG_07-63_Aug07.pdf.

[2] USACE, “Debris Management Overview Briefing," June 2006.

[3] Federal Emergency Management Agency, "Public Assistance Debris Management Guide," FEMA 325, July 2007, http:// www.fema.gov/government/grant/pa/demagde.shtm\#5. 
[4] USACE Emergency Planning Response-Debris Removal Magnolia and MS Field Office, "Field Evaluation Summary for Lincoln, Pike and Walthall Counties, Mississippi for Temporary Debris Reduction Sites (TDRS)," November 2005.

[5] USACE Emergency Field Office-Central, "Hurricane Katrina Debris Reduction Sites (Site Evaluations) Harrison County, Mississippi," November 2005.

[6] USACE Emergency Planning Response-Debris Removal Magnolia and MS Field Office, "Agreement between Mr. Alton Harvey and the USACE," November 2005.

[7] USACE Emergency Field Office-Central, "Hazard mitigation of abandoned swimming pools in pass christian, MS," April 2006.

[8] USACE Emergency Planning Response-Debris Removal Magnolia and MS Field Office, "Agreement between Jones Chip Mill and the USACE," November 2005.

[9] USACE Emergency Field Office-Central, "Concrete and tree assessments in pass christian, MS," July 2006.

[10] Air Conditioning, Heating and Refrigeration Institute. (AHRI), "Refrigerants and our environment," 2009, http:// phaseoutfacts.org/Content/RefrigernatsandOurEnvironment_ 35.aspx.

[11] USACE Vicksburg District, Hurricane Katrina Debris Removal Repository, Emergency Field Office-Central, 1180 General Corps of Engineers Contracts Correspondence Files, Dirty Whites-Pass Christian, 2006.

[12] USACE Vicksburg District, Hurricane Katrina Debris Removal Repository, Emergency Field Office-Central, 1180 General Corps of Engineers Contracts Correspondence Files, Vehicles and Vessels_-Pass Christian, 2006.

[13] USACE Vicksburg District, Hurricane Katrina Debris Removal Repository, Emergency Field Office-West, 1180 General Administrative Files, Tire Haul Outs Hancock County, 2006.

[14] USACE Emergency Planning Response-Debris Removal Magnolia and MS Field Office, "Remediation plan harvey temporary reduction site walthall county," April 2006.

[15] M. Jadacki, Review of FEMA Guidance for Monitoring Debris Removal Operations for Hurricane Katrina, Department of Homeland Security, Office of Inspector General, Washington, DC, USA, 2007.

[16] C. B. Cheah and M. Ramli, "The implementation of wood waste ash as a partial cement replacement material in the production of structural grade concrete and mortar: an overview," Resources, Conservation and Recycling, vol. 55, no. 7, pp. 669-685, 2011.

[17] D. R. Reinhart and P. T. McCreanor, "Disaster debris management-planning tools," Final Report, University of Central Florida and Mercer University, September 1999, Prepared for EPA Region IV, http://www.cece.ucf.edu/people/ reinhart/research/DDfinalreport.pdf.

[18] Mississippi Department of Environmental Quality, "Status Report on Solid waste disposal facilities calendar year 2004," Solid Waste Policy, Planning \& Grants Branch, Mississippi Department of Environmental Quality, Office of Pollution Control, 2005.

[19] URS Corporation, “Construction waste project," Solid Waste Management Coordinating Board (SWMCB), Twin Cities Metropolitan Area, Memo \#1, 2005.

[20] J. P. Zublena, A. R. Rubin, and D. A. Crouse, "Uses of sheetrock (gypsum) as a soil amendment," Soil Science Notes no. 1., Department of Soil Science, North Carolina State University, 1995.
[21] M. McPhee, "C\&D recycling in the home court," BioCycle, pp. 30-32, November 1997.

[22] R. H. Brickner, "Researching debris generation," Recycling Today, pp. 46-52, September 1995.

[23] M. Channell, M. Graves, V. Medina, A. Morrow, D. Brandon, and C. Nestler, Enhanced Tools and Techniques to Support Debris Management in Disaster Response Missions, ERDC/EL TR-09-12, USERDC, Vicksburg, Miss, USA, 2009.

[24] F. C. Edminster, W. S. Atkinson, and A. C. McIntyre, Streambank Erosion Control on the Winooski River, Vermont, Circular no. 837, United States Department of Agriculture, Washington, DC, USA, 1949.

[25] G. Y. Solis, H. C. Hightower, J. Sussex, and J. Kawaguchi, Disaster Debris Management, The Disaster Preparedness Resources Center, University of British Columbia, Center for Emergency Preparedness, Vancouver, Canada, 1995.

[26] J. E. Kurre, "Characterizing construction and demolition debris for lead contamination," Waste Age, vol. 28, no. 7, pp. 117-125, 1997. 

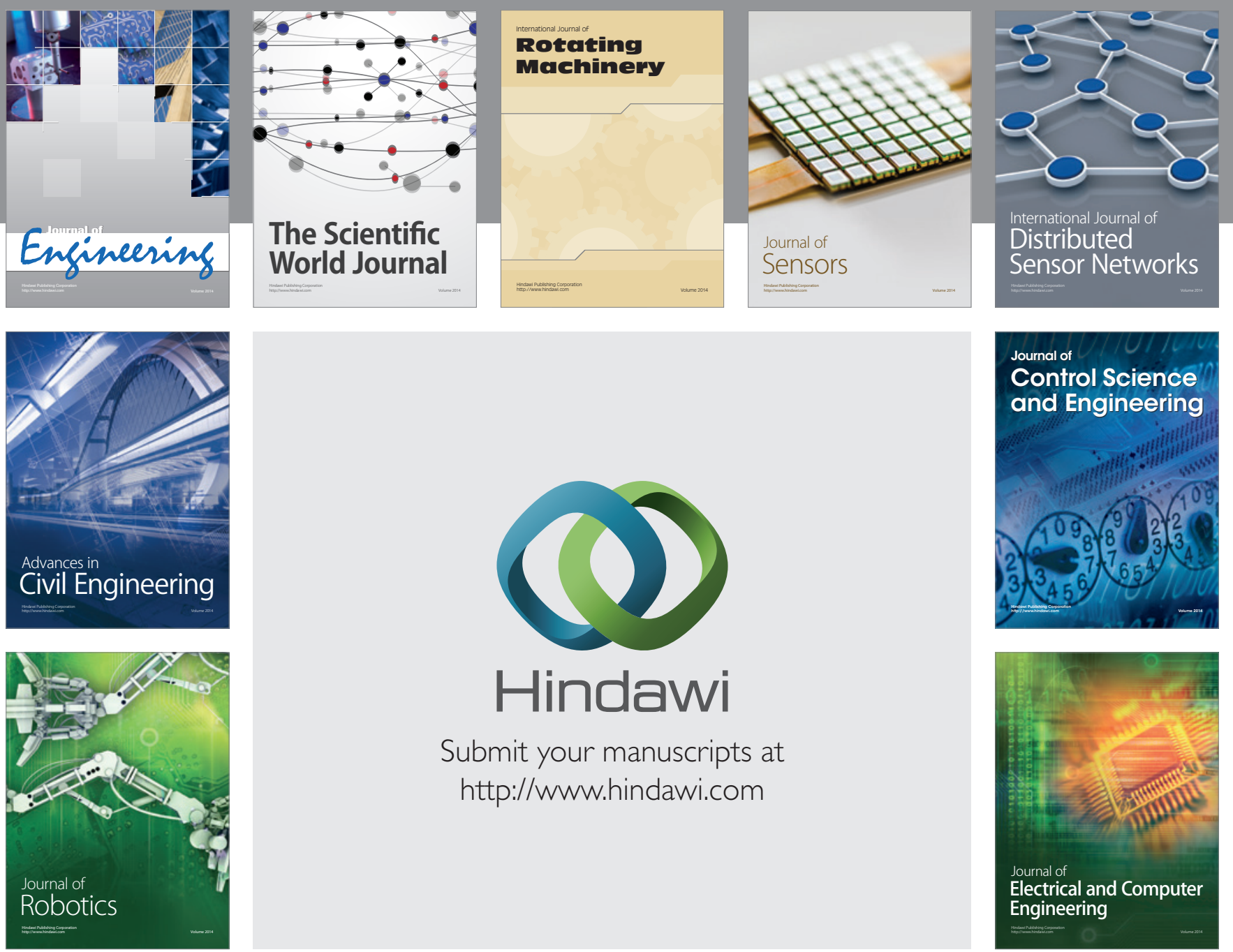

Submit your manuscripts at

http://www.hindawi.com
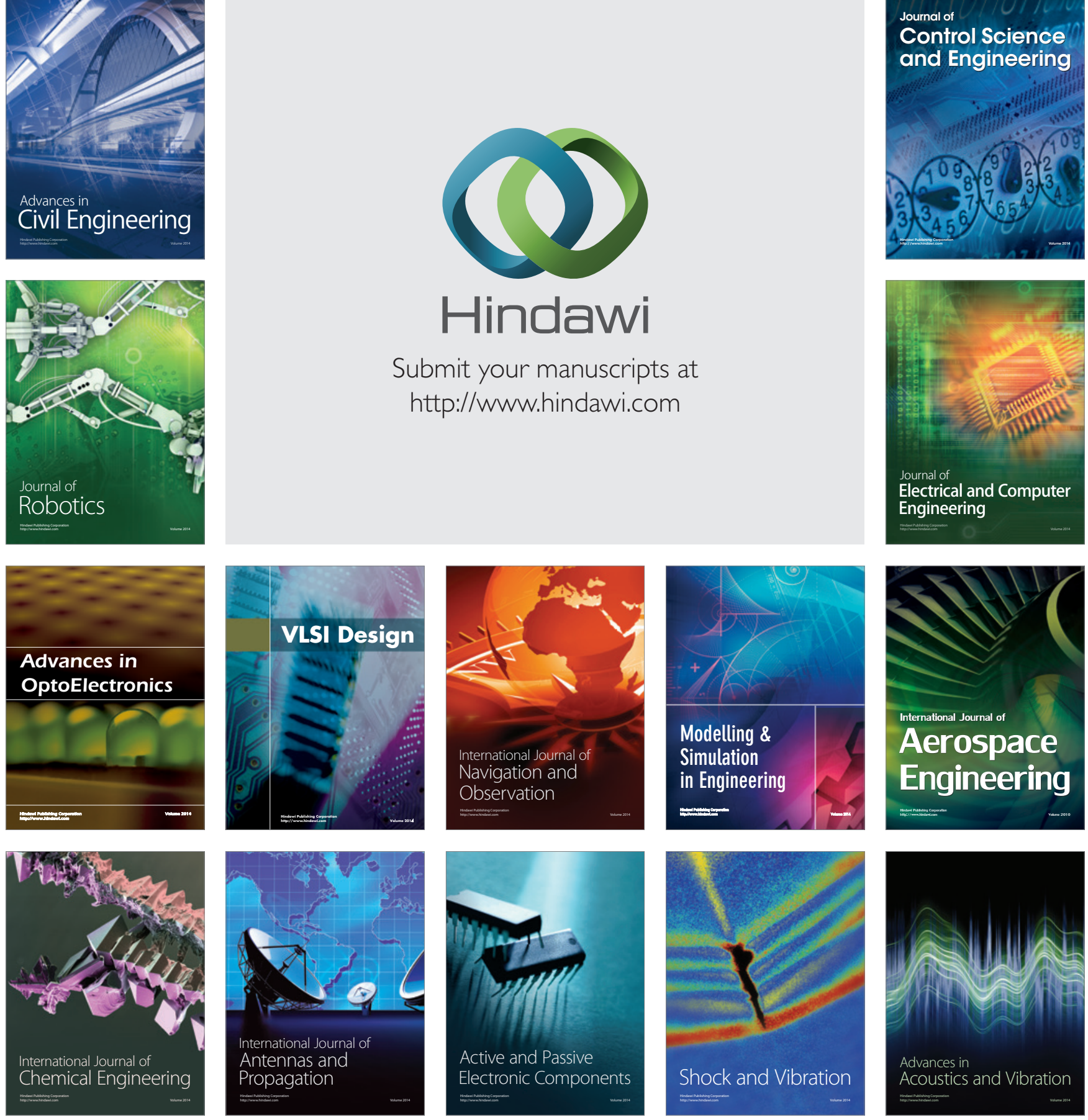